УДК $94(477.83 / 86)$

ФУРТЕС 0.0.

ПОТОЦЬКИЙ 0.0 .

\title{
ГОЛОВНІ НАПРЯМИ ДОСЛІДЖЕНЬ АРМІЇ УНР У НАУКОВИХ ПРАЦЯХ УКРАЇНСЬКОЇ ЕМІГРАЦІЇ
}

У статті проаналізовано та узагальнено головні напрями досліджень Армії Української Народної Республіки у наукових працях української еміграції. Досліджено творчу спадщину української еміграції Армії Української Народної Республіки. Визначено місце і роль української еміграції Армії Української Народної Республіки у боротьбі за українську державність.

Ключові слова: Українська народна революція, дослідження Армії Української Народної Республіки, українська еміграція, наукові праці, творча спадшина.

Актуальність даного дослідження зумовлена необхідністю більш грунтовного вивчення уроків Української національної революції, а саме: проаналізувати та узагальнити головні напрямки досліджень історії Армії Української Народної Республіки (далі - Армії УНР) у наукових працях української еміграції.

Постановка проблели. Складна сучасна воєннополітична ситуація в Україні навертає увагу сучасних істориків до вивчення подій столітньої давнини, що розкриває нам творчий доробок безпосередніх учасників подій Української національної революції.

Аналіз останніх досліджень $i$ публікаиій. Аналіз наукових праць [1-3] свідчить, що дослідження творчого доробку української еміграції Армї УНР не залишились поза увагою вітчизняних дослідників, проте їх праці не мають узагальнювальний характер.

Фуртес Олексій Олександрович, кандидат історичних наук, старший науковий співробітник, провідний науковий співробітник Наукового центру Сухопутних військ, Національна академія сухопутних військ імені гетьмана Петра Сагайдачного, м. Львів.

Потоцький Олександр Олексійович,науковий співробітник Наукового центру Сухопутних військ, Національна академія сухопутних військ імені гетьмана Петра Сагайдачного, м. Львів.

(c) Фуртес О.О., Потоцький O.O., 2017 
Mema cmammi - дослідити творчу спадщину української еміграції Армї УНР і визначити їі місце і роль у боротьбі за українську державність.

Виклад основного матеріалу дослідження $з$ повнил обтрунтуваннял отриланих наукових результатів. Поразка Української національної революції 1917-1921 рр., коли за межами України опинилося близько 100 тис. наших співвітчизників, із них не менше 40 тис. козаків, старшин і генералів Армії УНР [3, с. 24], не зупинила державно-соборного процесу. Особливість цієї хвилі еміграції полягала в тому, що, прагнучи продовжити визвольні змагання, українське військо з командуванням та урядом держави відступило до союзної Польщі. Головний Отаман Симон Петлюра наказав Військовому міністрові після переходу польського кордону 23 листопада 1920 р. «...ні одної частини, підлеглій Військовому Міністерству, не розпускати. Вони повинні розташуватись на загальних умовинах інтернування в цілях організації підготовчої праці для повернення на Вкраїну» [4, Оп. 2, спр. 32, арк. 69]. У ті ж дні голова Української військової місії у Варшаві генерал Віктор Зелінський у листі до колишнього начальника штабу військ Антанти генерала Максима Вейгана писав: «Незважаючи на обмежені свободи i відсутність матеріальних засобів, наші вояки не падають духом, а інтенсивно працюють над своєю загальною i національною освітою... Армія чекає того щасливого дня, коли ми, відпочивши у Польщі, зорганізованою силою і зі зброєю в руках знову вступимо на терени нашої змученої Батьківщини, яка 3 нетерпінням чекає нас, i щоб допомогти нашому народові вигнати окупантів 3 нашої землі» [5, Оп. 2, спр. 479, арк. 154].

Розмістивши у таборах на території Польщі дивізї i полки Армї УНР,командири із перших днів інтернування розгорнули широкомасштабну вишкільну та національнопатріотичну роботу. Зусиллями командного складу, армійського та дивізійних культурно-освітніх відділів при 
військових штабах, високоосвічених генералів і старшин у таборах розпочалася інтенсивна фрахова, культурноосвітня та релігійно-виховна робота, підпорядкована новій воєнно-політичній доктрині. Основою їі концепції було зберегти боєздатну армію для майбутньої боротьби за визволення України. Для цього було відновлено діяльність Спільної Юнащької школи підготовки старшин i дивізійних шкіл підстаршин, засновано академічні курси Генерального штабу. Щоб забезпечити національно-патріотичне виховання, створено громадські, фахові літературно-мистецькі товариства, релігійні громади, налагоджено видання часописів і журналів, навколо яких гуртувалися військові історики, письменники й журналісти.

Зауважимо, що в інтернованих частинах Армї УНР зосередився могутній інтелектуальний потенціал українських військовиків, зокрема генералів і старшин Генерального штабу - відданих українській справі учасників визвольних змагань 1917-1921 pр. Серед них генерал-полковники: колишній профресор Миколаївської академії Генштабу, автор низки військово-наукових праць Микола Юнаків, начальники офіцерських училищ С. Дельвіг і М. Омелянович-Павленко; генералпоручники: . Дядюша, О. Греков, П. Срошевич, О. Удовиченко; генерал-хорунжі: В. Змієнко, В. Кущ, В. Петрів, М. Садовський та багато інших [6; 7].

Потужний інтелектуальний потенціал військовиків, насамперед вищого рангу, дав змогу у складних умовах еміграції створити великий за обсягом і унікальний за змістом пласт воєнно-історичних праць, які склали надзвичайно цінну джерельну базу для майбутніх науковців і дослідників.

Визначальним напрямом досліджень, безперечно, була історія Української революції 1917-1921 pp., за висловом В. Солдатенка, «одніеї з найяскравіших і найпритягальніших сторінок вітчизняної історії» [8, с. 418].

Велику увагу дослідників привернув, насамперед, складний процес військового будівництва доби 
Центральної Ради, зокрема Всеукраїнські військові з'їзди, українізація російської армії, утворення воєнного відомства та формування перших частин Української армії. Історіографрія цього періоду охоплюе велику збірку мемуарів, розвідок i аналітичних праць таких військовиків, як В. Прохода, В. Кедровський, В. Савченко, М. Омелянович-Павленко, М. Падалка, . Монкевич, В. Сальський, Ю. Науменко, В. Свтимович, Б. Сульківський та ін. [9].

Велике значення Всеукраїнських військових з'їздів для розвитку i піднесення самостійницьких державницьких ідей Української револющії особливо переконливо висвітлив у працях «Українська армія та Головний Отаман Симон Петлюра» і «Вождь та військо» підполковник $\quad$ В. Прохода [10]. «Найсвітлішими моментами першого періоду Української революції е 1-й і 2-й Всеукраїнські військові з'їзди, у яких виявився стихійний рух народних мас до власних форм українського державного життя, - зазначав він. - На цих з'їздах прокинувся ніби цілком знищений дух військовокозацької вдачі української нації. На них вітав дух Мазепи, якого всіма силами намагалися прогнати провідники російської революції» [10, с. 112].

Чимало уваги приділено бойовим діям українського війська при обороні Києва у січні-лютому 1918 р. Відзначимо, насамперед, книгу В. Петріва «Спомини 3 часів української революції (1917-1921)». Генерал об'єктивно відтворив діяльність С. Петлюри в період першої українсько-більшовицької війни. Він вказав на важливе значення сформованого Петлюрою Гайдамацького Коша Слобідської України в обороні української столиці. Саме в ньому розпочинав свій бойовий шлях штабс-капітан О. Удовиченко. Поруч із ним воювали визначний артилерійський командир, майбутній генерал К. Смовський, а також полковник О. Сливінський - згодом начальник Генштабу [11, ч. 1. с. 107]. У розвідщі «Перша боротьба за Київ» О. Удовиченко наголошував на національній 
свідомості й патріотизмі гайдамаків, які добровільно вступали до Коша, складали присягу на вірність Україні. Відтак, у боях із ворогом виявляли високі бойові якості [12, с. 13].

Чи не найбільше спогадів і воєнно-історичних розвідок було присвячено бою під Крутами у січні 1918 р. Історіографія проблеми надзвичайно велика: за бібліографією, яку склав А. Фігель, 1933 р. вона нараховувала 90 спогадів, розвідок і аналітичних статей [13].

Літописців Української революції привернула увагу оборона Киева, вуличні бої у столищі під час ліквідації антидержавного збройного більшовицького повстання, яке вибухнуло при наступі війська М. Муравйова. У згаданій праці В. Прохода слушно зауважив: «Бої у Києві мали дуже велике значення, бо якраз тоді велись мирові переговори 3 Осередніми державами: Німеччиною, Австро-Угорщиною, Болгарією та Туреччиною в Бересті. Російський більшовицький уряд намагався за всяку ціну зірвати ці переговори опануванням столиці України» [10, с. 125].

Багатьом військовим історикам 3 українського зарубіжжя імпонувала діяльність гетьмана П. Скоропадського, який у складних умовах німецької окупації розгорнув широке військове будівництво, перерване антигетьманським повстанням Директорії восени 1918 р. За свідченням О. Удовиченка, «... уже наприкінці червня, тобто через два місяці, Українська армія мала Запорізький корпус (3,5 тис. вояків), Синю дивізію (6 тис. багнетів), Сіру дивізію (4 тис.), відділ Січових Стрільців (3 тис.), усього 35 тис. багнетів. Зважаючи на помилки Центральної Ради, уряд гетьмана приступив до формування нової Української армї в складі 16-ти піших і 8-ми кінних дивізій. В першу чергу відновлено було та реорганізовано апарати Головного і Генерального Штабів. Як в першому, так і другому працювало до 150 старшин генерального штабу» [14, с. 40-43].

Широкомасштабну діяльність нового проводу України висвітлив М. Омелянович-Павленко у книжці «На Україні 
1917-1918». Насамперед, він відзначив, що розбудовою війська займалися досвідчені й віддані українській справі генерали О. Галкін, М. Юнаків, В. Зелінський, С. Дельвіг, О. Рагоза (військовий міністр), Г. Базильський, полковник О. Бурківський, М. Крат, О. Удовиченко, О. Алмазов та ін. Генерал-полковник звернув увагу на помилкову позицію Центральної Ради, коли навесні 1918 р. "вже ніхто не думав про відновлення Вільного Козацтва». Між тим саме за Гетьманату «поруч з плянами реорганізації армї стало на чергу питання про відродження на Україні козацтва вже як стану, чим воно грунтовно відріжнялося від Вільного Козацтва... Позитивною стороною козацтва було те, що воно набирало яскраво національних барв. Досить перерахувати прізвища деяких кошових отаманів, щоб погодитися 3 тим, що гетьман передав цю справу в руки тих, яких болів успішний перебіг національної революції» $[15$, c. 88$]$.

Загалом схвально оцінював військове будівництво за часів Гетьманату й 3. Стедранів, який відзначав, що новостворена 300-тисячна армія, національна за ознаками i внутрішнім укладом, мала бути гарантом незалежності Української держави. Ї̈̈ ядром стали вісім армійських корпусів: волинський, подільський, одеський, київський, чернігівський, полтавський, харківський i катеринославський - корпуси, які очолювали здебільшого генерали-українці. Водночас військовий історик відзначав негативні тенденщії при формуванні війська: «Старшин приймали тільки з передвоєнними кваліфікаціями. Через те до армї ввійшли старшини, хоч і фахово освічені, але 3 національного огляду байдужі. Прийнято дуже багато старшин-москалів, що взагалі вороже ставилися до українства». Щоправда, відзначав автор, військове міністерство, в якому працювало чимало національно свідомих українських генералів і старшин, віддало наказ «приймати до війська старшин воєнного часу, що складалися в великій частині 3 патріотично настроєної української інтелігентської молоді» [16, с. 426-429]. 
Чимало спогадів та воєнно-історичних праць налічує історіографія антигетьманського повстання. Головною ударною силою Директорії були січові стрільці Окремого загону, який під час бойових дій перетворився на Осадний корпус під командуванням Свгена Коновальця. Найповніше ці події висвітлили колишній командир корпусу, начальник штабу корпусу генерал Марко Безручко, командувач артилерї корпусу генерал Роман Дашкевич і полковник Василь Кучабський. Майже усі відзначали перемогу січовиків під Мотовилівкою, що стала визначальною у повстанні. Саме там, відзначали автори, були розгромлені найкращі частини гетьмана. «Мотовилівський бій вирішив долю гетьманщини», писав Є. Коновалець [17, с. 18]. Генерал Р. Дашкевич, змалювавши дуже докладно хід битви, відзначав масовий героїзм січового стрілецтва. "Січові Стрільці перемагали у багатьох боях, - згадував він у книжці «Артилерія Січових Стрільців у боротьбі за Золоті Ворота», - але перемога під Мотовилівкою над ворогом, який був бодай уп'ятеро сильніший від Січових Стрільців, була повна... Сама перемога була така цілковита, що ворог по тім бою не важився вже ставити спротив» [18, с. 90].

Основним творчим напрямом роботи українського зарубіжжя стало дослідження найбільш драматичного періоду Української революції - друга українськобільшовицька війна. Вагомі творчі здобутки представлені, насамперед, працями відомих воєначальників: О. Удовиченка, М. Капустянського, Є. Коновальця, Р. Дашкевича, М. Безручка. Значний внесок у дослідження проблематики зробили спогади й розвідки генералів П. Єрошевича, М. Коваль-Медзвецького, В. Савченка, В. Чабанівського, О. Вишнівського, полковників М. Середи, I. Андруха, Г. Порохівського, П. Свтимовича, І. Ремболовича та ін. [9].

Насамперед, відзначимо книжку О. Удовиченка «Україна у війні за державність», в якій об’єктивно висвітлено події 1919 р. Серед чинників, що визначали перебіг подій, автор монографії аналізує внутрішньо- i 
зовнішньополітичну ситуацію, в якій опинилася УНР. На його думку, друга українсько-більшовицька війна була виявленням неприкритої агресї більшовицької Росії. «Москва уважно стежила за подіями на України, - писав він, - та чекала на слушний момент, щоб підбити їі під свою владу». Такою слушною нагодою стала евакуація 3 України німецько-австрійських військ, які, безперечно, стримували Москву від чергового нападу. Щоправда, автор значно перебільшував сили більшовиків, вважаючи, що в наступ перейшло військо чисельністю близько 86 тис. вояків [14, с. 50]. Але їх було достатньо, щоб зайняти Київ і змусити взимку 1919 р. 50-тисячну Армію УНР, дивізії якої були розкидані по всіх фрронтах, відступити. У травні польські війська розгромили Холмську групу УНР і зайняли майже всю Волинь. У зв’язку 3 цим О. Удовиченко писав: “Становище Української Армії було катастрофральним... В кінці травня 1919 р. Українська Армія була вже фрактично оточена 3 одного боку червоними, а 3 другого - поляками» $[14$, с. 50 51]. Далі історик розглянув, як приєднання Галицької армії сприяло зміні ситуації на більшовищькому фрронті; вдалося здійснити блискучу Київську наступальну операцію. О. Удовиченко зробив глибокий аналіз причин поразки національно-визвольної боротьби українського народу в 1917-1920 pp. [14, с. 119-121]. Генерал із прикрістю відзначав, що в напруженій боротьбі проти комуністичної Москви, яка загрожувала всій Свропі, країни Заходу не надавали Україні найменшої допомоги, навпаки, підтримували Польщу й Денікіна у війні проти неї. «Ніхто не розумів, - писав О. Удовиченко, - що Українська Армія з 1917 до 1921 р. стримувала московську червону армію від походу на Захід i тим рятувала Європу від більшовицької навали» [14, с. 166].

Відзначимо також фундаментальну працю генералполковника Миколи Капустянського «Похід Українських Армій на Київ-Одесу в 1919 р.», перший том якої вийшов у Львові вже 1921 р. [19; 20]. Непересічне значення для 
об'єктивного висвітлення цього дослідження історії Української революції відзначав О. Удовиченко: «Ця книга - то є фрундаментальний історичний матеріал про нашу боротьбу. Будучи майже постійним генералквартирмайстером Штабу нашої Армії, чи на інших постах зверхнього керівництва Армією, він (М. Капустянський. - Авт.) яскраво освітлюе бойові операції, хиби, заслуги командного складу та умови, в яких наша боротьба відбувалася» [14, с. 168]. До речі, саме за неоднозначний розгляд подій i незалежні думки C. Петлюра по-іншому оцінив дослідження М. Капустянського, писавши О. Удовиченкові, що автор висловив чимало «скороспілих епітетів та висновків... в оцінці подій і окремих осіб» [21, с. 227].

Серед багатьох тем досліджень наддніпрянських військових істориків в еміграції була отаманщина, яку сучасний історіографр В. Солдатенко визначив як «суспільний феномен» Української революції [22, с. 298]. Численні дослідники - М. Середа, О. Удовиченко, М. Капустянський, Є. Коновалець, А. Голуб, О. Вишнівський та інші - визнавали: отаманщина - закономірне явище в умовах слабкої центральної влади, яка до того ж часто мінялася, в умовах соціально-політичних і воєнних потрясінь, коли стихія опановувала малосвідомими масами. У 1919-1920 рр. вона охопила всю Україну. Утворилися десятки і сотні загонів під командуванням амбітних, часто анархічно настроєних отаманів, чиї прагнення були далекі від загальнонаціональних. Однак чимало військових істориків ідеалізувало у своїх працях отаманщину, схвалювали їі спрямованість проти більшовицької влади й закривали очі на інші риси повстанського руху. Зокрема, чи не найбільше писав на цю тему полковник М. Середа. Його основну працю «Отаманщина» публікували в журналі «Літопис Червоної Калини» упродовж 1929-1930 pp. [9, 1974, № 1-3, с. 61].

Значну частку історіографії визвольного руху займала одна 3 останніх операцій Армії УНР - Перший Зимовий 
похід (грудень 1919 - травень 1920 рр.). Серед праць ціеї проблематики відзначимо монографію тогочасного командувача армї М. Омеляновича-Павленка «Зимовий похід», що вийшла 1934 р. у Каліші (журнал «За державність» публікував іï в 1929-1933 рр.); надзвичайно цінне дослідження 3 додатком багатьох документів підполковника О. Доценка «Зимовий похід (6.XII.19196.V.1920)», що побачило світ у Варшаві 1932 р. заходами Українського наукового інституту; мемуарно-аналітичну «Україну в огні і бурі революції 1917-1921» учасника походу, члена уряду УНР І. Мазепи; книжку командира дивізії генерала Ю. Тютюнника «Зимовий похід 19191920» (Коломия, 1923). Цій темі присвячено розвідки i спогади військових істориків Б. Монкевича, В. Сальського, М. Чижевського, П. Феденка, П. Певного та інших [9].

Увага дослідників з української військової еміграції до Зимового походу Армії УНР пов'язана з унікальністю ціеї операції. Затиснута більшовицькими військами до західного кордону України, знекровлена 8-тисячна Армія УНР опинилася в безвихідному становищі, на межі інтернування в Польщі. Але їі морально-бойовий дух не було зломлено. «Боротьбу за визволення України мусимо провадити далі, відображаючи настрій вояцтва, писав генерал М. Омелянович-Павленко, - але в інший спосіб партизанський... перекинути на вороже запілля, дезорганізувати ворожі тили, комунікації і засоби зв'язку, організувати повстанський рух, підтримати серед населення віру у справу нашу, а найголовніше - переховати до наступної весни кадри армїі» [23, Зб. 1, с. 11].

Серед історіографічних матеріалів про Зимовий похід чи не на перше місце слід поставити працю О. Доценка, яка містила неопубліковані архівні документи: накази командування, оперативні звіти, листування, картосхеми. Визначаючи концепцію видання, автор слушно зауважував: «Переповідаючи в хронологічно-літописному порядкові перебіг подій, я не претендую на широку i 
всебічно-критичну оцінку використаних матеріалів, обмежуюсь тільки оцінками, опертими на об'єктивних даних, документах, та поправками чужих помилок i неточностей, коли на те мене уповноважують мої матеріяли або висновки» [24, с. V]. Одним із перших українських військових істориків О. Доценко започаткував важливий напрям історичної науки публікацію збірників документів. Усвідомлюючи актуальність ціеї роботи, він зазначав: «В упорядкованій мною збірці майбутні дослідники-історики завжди будуть мати точно видані документи й матеріали, які, коли б $\mathrm{i}$ загинули їх оригінали, залишаться як свідоцтво героїчних зусиль нашого війська в боротьбі за свободу й державність нації» [24, с. IV].

Зазначимо також низку праць, присвячених Другому Зимовому походові - останній збройній операції групи із складу інтернованої Армї УНР під командуванням генерала Юрка Тютюнника (листопад 1921 р.). Незважаючи на деяку тенденційність у викладі матеріалу у праці «З поляками проти Вкраїни» Ю. Тютюнник розглянув підготовку 2-тисячної української групи, діяльність Партизансько-Повстанчого штабу у Львові, наголосивши, що вояки були дуже погано озброєні i забезпечені. Зокрема, тільки половина бійців мала рушниці [25]. Трагічне завершення Зимового походу, кульмінацією якого став кровопролитний бій у с. Миньки i розстріл червоними 359 полонених українських вояків під Базаром, викликало широкий відгомін у середовищі військово-політичної еміграції. Внаслідок цього з'явилися численні спогади, розвідки, літературні твори, присвячені цій операції. Проте виклад матеріалу в них був надто емоційним, містив чимало фрактографічних розбіжностей. Тематичний випуск збірника «За державність» 1933 р., в якому було опубліковано праці безпосередніх учасників походу старшин I. Ремболовича, С. Чорного, М. Чижевського, П. Ващенка й О. Шпілінського, став значним внеском в об’єктивне відтворення Листопадового 
рейду [23]. Зазначимо також праці сотника Гриця Рогозного «Листопадовий рейд», Віктора Яновського «За Україну, за їі волю», Дмитра Зоренка «На партизанці», які опубліковані згодом у збірникові «Другий Зимовий похід: Листопадовий рейд. Базар» [26]. У різних виданнях вийшли друком мемуарно-аналітичні твори командира однієї з бригад групи Тютюнника, полковника Романа Сушка «Базар: могила 359 героїв» та Олександра Вишнівського «Повстанський рух і отаманія» [27, 1930, c. 104-127; 195]. Надзвичайно цінним джерелом для дослідників була публікація начальника штабу групи, полковника Юрка Отмарштайна «До історії повстанчого рейду генерал-хорунжого Ю. Тютюнника в листопаді 1921 р. Доклад Головному Отаманові» [28].

Автори більшості праць, особливо мемуарних, акцентують на героїзмі українських вояків, підтримці населення тимчасово визволених місцевостей, самопожертві 359 полонених, які були готові прийняти смерть, аніж перейти на службу до більшовиків.

Висновки з дослідження $i$ перспективи подальших розвідок у данолу напрялі. Справжнім національним феноменом, який вразив політиків і загалом суспільство західних держав, стало те, що після кількох років визвольних змагань розрізнені, змучені духовно i фрізично, залишки Армії УНР, викинуті за межі Батьківщини, у надзвичайно складних умовах інтернування зуміли створити міцні центри української науковоосвітньої діяльності та залишити по собі величезний доробок наукових праць, присвячених осмисленню подій Української національної революції 1917-1921 рр.

Творча спадщина української військової еміграції Армї УНР в галузі історичної науки стала не лише внеском у піднесення національної свідомості та державницького самостійного духу українства, але й нерідко єдиною джерельною базою для сучасних дослідників визвольних змагань українського народу в $\mathrm{XX}$ ст. Домінуючим напрямом узагальнюючих досліджень 
і мемуарно-аналітичних праць військовиків українського зарубіжжя була історія Української національної революції 1917-1921 рр., аналіз їі соціально-політичних здобутків і причин поразки.

Дослідження й аналіз творчих здобутків військової еміграції УНР дозволяють зробити висновок, що саме їй належить провідна роль у розвитку української військовоісторичної науки доби Української національної революції 1917-1921 pp. Домінуючою концепціею переважної більшості наддніпрянських істориків стало трактування Української революції виключно як революції національної, головною метою якої було осягнення незалежності України і збройний захист иї суверенітету. Водночас вони критично ощінювали діяльність лідерів Центральної Ради за нездатність своєчасно створити власні збройні сили та соціальну спрямованість пї провідників. Найбільше уваги у цих студіях приділялося військовим аспектам державотворення: формуванню

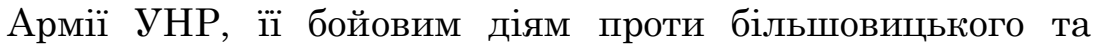
денікінського війська, аналізу невдач i поразок. Усі воєнно-історичні та мемуарно-аналітичні праці пронизані патріотизмом, вірою в остаточну перемогу українського народу. Поразка Української революції 1917-1921 рр. вважалася як тимчасова невдача у ході стратегічного поступу у боротьбі за свободу. I хоча вона не досягла своєї мети, але внутрішньо переродила суспільство України, заклавши фрундамент під сучасну політичну націю.

Більш грунтовно дослідити події Української національної революції 1917-1921 рр. дозволить творчий доробок української еміграції ЗУНР та Української держави часів Гетьманату П. Скоропадського. 
1. Голубко В. Армія Української Народної Республіки, 1917-1918: утворення та боротьба за державу / Віктор Голубко. - Львів, 1997. - 288 с.

2. Голубко В.Є. Військове будівництво Павла Скоропадського: плани і реалії / Віктор Голубко // Держава та армія. Вісн. ун-ту «Львів. політехніка». - 1999. - № 377 - С. 28-39.

3. Колянчук $O$. Українська військова еміграція у Польщі 1920-1939 / О. Колянчук. - Львів, 2000. $274 \mathrm{c}$.

4. ЦДАВОВУУ, фр. 1429. Канцелярія Директорії УНР.

5. ЦДАВОВУУ, ф. 1075 . Міністерство військових справ Української держави.

6. Колянчук $O$. Генералітет українських визвольних змагань. Біограми генералів та адміралів українських військових формацій першої половини ХX століття / О. Колянчук, М. Литвин, К. Науменко. - Львів: Інститут українознавства ім. І. Крип’якевича НАН України, 1995. - 288 с.

7. Науменко К.Генералітет Української Народної Республіки / К. Науменко // Polska i Ukraina. Sojusz 1920 roku i jego nastkpstwa. - Toruc 1997. - S. 217-234.

8. Солдатенков В.Ф. Українська революція: історичний нарис / В. Солдатенко. - Кииів: Либідь, 1999. - 976 с.

9. Шанковський Л. Нарис української военної історіографрії / Лев Шанковський // Український історик. - 1970. - Ч. 4 (28) - С. 67-75; 1971. - № 1-2 (29-30). - C. 58-69; № 3-4 (31-32). - C. 31-32; 1972. Ч. $3-4(35-36)$ - - C. $55-71 ; 1973$. - Ч. 3-4 (39-40). C. $113-126 ; 1974-$ Ч. $1-3$ (41-43). - C. $48-64 ; 1975-$ Ч. 1-2 (45-46). - C. $45-69$.

10. Прохода В. Вождь та військо / В. Прохода // Збірник нам'яти Симона Петлюри (1879-1926). - ІІрага: Накладом Міжорганізаційного комітету для вшанування пам'яти Симона Петлюри в Празі. 1930. - C. 109-148.

11. Петрів В. Спомини з часів української революції (1917-1921) / В. Петрів. - Львів: Червона Калина, 1927-1931. Ч. 1-4. - 180 c.; 184 c.; 164 c.; 120 c.

12. Удовиченко O. Перша боротьба за Київ/ О. Удовиченко // Тризуб. - 1927. - Ч. 45. - С. 13-15.

13. Фіголь А. Бібліографрія джерел до історії бою під Крутами / А. Фіголь // Студентський шлях. - Львів, 1933. - Ч. 1. - С. 7-11; Ч. 2. - C. 15-23.

14. Удовиченко O. Україна у війні за державність: Історія організації і бойових дій Українських 
Збройних Сил 1917-1921 / О. Удовиченко. - К.: Україна, 1995. - 206 с.

15. Омелянович-Павленко М. На Україні 1917-1918. Спомини / М. Омелянович-Павленко. - Прага: Стилус, 1935. - 72 с.

16. Історія українського війська (від княжих часів до 20-х pp. ХХ ст.) / [під ред. І. Крип'якевича, Б. Гнатевича, З. Стефаніва та ін.]. - Львів: Видавництво I. Тиктора, 1936. - 801 с.

17. Коновалець $\epsilon$. Причинки до історії української революції / Є. Коновалець. - [Б. м.]. - Наклад Проводу Українських націоналістів, 1948. - 48 с.

18. Дашкевич P. Артилерія Січових Стрільців у боротьбі за Золоті київські ворота / Р. Дашкевич. Нью-Йорк, 1965. - 208 с.

19. Капустянський $M$. Похід українських армій на Київ-Одесу в 1919 році (Короткий военноісторичний огляд) / М. Капустянський. - Львів: Діло, 1921. - Кн. 1 (Ч. І й ІІ). - 88 с.

20. Капустянський $M$. Похід українських армій на Київ-Одесу в 1919 році (Короткий военноісторичний огляд) / М. Капустянський. - Львів: Діло, 1921. - Кн. 2 (Ч. ІІІ). - 192 c.

21. Петлюра С. Статті / Симон Петлюра: [упор. та автор передм. О. Климчук]. - К.: Дніпро, 1993. $341 \mathrm{c}$.

22. Солдатенко В. Українська революція. Концепщія та історіографія (1918-1920рр.) / В. Солдатенко. К.: Просвіта. 1999. - 507 с.

23. За державність. Каліш; Варшава, 1929-1939.

24. Доценко О. Літопис Української революції. Матеріали і документи / О. Доценко. Т. 2, Кн. 5. Берестейський мир. 3 нагоди $10-\mathrm{x}$ роковин. 9.11.1918-9.11.1928. - Львів; Київ, 1928. - 400 с.

25. Тютюнник Ю. 3 поляками проти України / Ю. Тютюнник. - Харків: Держвидав України, 1924. - $101 \mathrm{c}$.

26. Другий зимовий похід: Листопадовий рейд. БазарКиїв, 1995. - 238 с.

27. Історичний календар-альманах Червоної калини. Львів, 1920-1939.

28. Отмларштайн Ю.В.До історії повстанчого рейду генерал-хорунжого Ю. Тютюнника в листопаді 1921 р. / Ю.В. Отмарштайн // Л. Ч. К. - 1930. - Ч. 6. C. $12-13$; Ч. $7 / 8$. - C. $17-20$. 
Надійшла до редколегії 07.02.2017 p.

Рецензент: М.Я. Нагірняк, кандидат історичних наук, доцент, доцент кафедри гуманітарних дисциплін та соціальної роботи, Львівський державний університет безпеки життедіяльності, м. Львів.

\section{Фуртес А.А., Потоцкий А.А. \\ ГЛАВНЫЕ НАПРАВЛЕНИЯ ИССЛЕДОВАНИЙ АРМИИ УНР В НАУЧНЫХ ТРУДАХ УКРАИНСКОЙ ЭМИГРАЦИИ}

В статье проанализированы и обобщены главные направления исследований Армии Украинской Народной Республики в научных трудах украинской эмиграции. Исследовано творческое наследие украинской эмиграции Армии Украинской Народной Республики. Определено место и роль украинской эмиграции Армии Украинской Народной Республики в борьбе за украинскую государственность.

Ключевые слова: Украинская народная революция, исследование Армии Украинской Народной Республики, украинская эмиграция, научные труды, творческое наследие.

Furtes A., Pototsky A.

MAIN RESEARCH LINES OF UPR ARMY IN SCIENTIFIC PAPERS OF UKRAINIAN EMIGRATION

In main research lines of Ukrainian People's Republic Army in the scientific works of the Ukrainian emigration had been analyzed and summarized. Creative heritage of the Ukrainian emigration of Ukrainian People's Republic Army had been investigated. The place and role of Ukrainian emigration Ukrainian People's Republic Army in the struggle for Ukrainian statehood had been identifying.

Keywords: Ukrainian national revolution, researchof Ukrainian People's Republic Army, Ukrainian emigration, scientific papers, creative heritage. 